\title{
Comparative proteomics of inhaled silver nanoparticles in healthy and allergen provoked mice
}

This article was published in the following Dove Press journal:

International Journal of Nanomedicine

2 August 2013

Number of times this article has been viewed

\author{
Chien-Ling Su ${ }^{1,2}$ \\ Tzu-Tao Chen ${ }^{1,3}$ \\ Chih-Cheng Chang ${ }^{1,3}$ \\ Kai-Jen Chuang $g^{4,5}$ \\ Cheng-Kuan $\mathrm{Wu}^{6}$ \\ Wen-Te Liu ${ }^{1,2}$ \\ Kin Fai $\mathrm{Ho}^{7}$ \\ Kang-Yun Lee ${ }^{1,8}$ \\ Shu-Chuan $\mathrm{Ho}^{2,8}$ \\ Hsiu-Er Tseng 9 \\ Hsiao-Chi Chuang ${ }^{1,2}$ \\ Tsun-Jen Cheng ${ }^{6,10}$ \\ On behalf of the Taiwan \\ CardioPulmonary Research \\ Group (T-CPR) \\ 'Division of Pulmonary Medicine, Department \\ of Internal Medicine, Shuang Ho Hospital, \\ ${ }^{2}$ School of Respiratory Therapy, College of \\ Medicine, ${ }^{3}$ Graduate Institute of Clinical \\ Medicine, College of Medicine, ${ }^{4}$ Department \\ of Public Health, School of Medicine, College \\ of Medicine, ${ }^{5}$ School of Public Health, College \\ of Public Health and Nutrition, Taipei Medical \\ University, ${ }^{6}$ Institute of Occupational Medicine \\ and Industrial Hygiene, College of Public \\ Health, National Taiwan University, Taipei, \\ Taiwan; ${ }^{7}$ School of Public Health and Primary \\ Care, The Chinese University of Hong Kong, \\ Hong Kong, People's Republic of China; \\ ${ }^{8}$ Department of Thoracic Medicine, Chang Gung \\ Memorial Hospital, Chang Gung University \\ College of Medicine, ${ }^{9}$ Division of Consultation \\ and Promotion, Taiwan Drug Relief Foundation, \\ ${ }^{10}$ Department of Public Health, College of Public \\ Health, National Taiwan University, Taipei, Taiwan
}

Correspondence: Hsiao-Chi Chuang

School of Respiratory Therapy, College

of Medicine, Taipei Medical University,

Taipei, Taiwan

Tel +886 22736 I66I ext $35 \mid 5$

Fax +88622739 || 43

Email r92841005@ntu.edu.tw

Tsun-Jen Cheng

Institute of Occupational Medicine

and Industrial Hygiene and Department of Public

Health, College of Public

Health, National Taiwan University,

Taipei, Taiwan

Tel +88623366 8090

Fax +886223957845

Email tcheng@ntu.edu.tw
Background: Silver nanoparticles (AgNPs) have been associated with the exacerbation of asthma; however, the immunological basis for the adjuvant effects of AgNPs is not well understood.

Objective: The aim of the study reported here was to investigate the allergic effects of AgNP inhalation using proteomic approaches.

Methods: Allergen provoked mice were exposed to $33 \mathrm{~nm}$ AgNPs at $3.3 \mathrm{mg} / \mathrm{m}^{3}$. Following this, bronchoalveolar lavage fluid (BALF) and plasma were collected to determine protein profiles.

Results: In total, 106 and 79 AgNP-unique proteins were identified in the BALF of control and allergic mice, respectively. Additionally, 40 and 26 AgNP-unique proteins were found in the plasma of control and allergic mice, respectively. The BALF and plasma protein profiles suggested that metabolic, cellular, and immune system processes were associated with pulmonary exposure to AgNPs. In addition, we observed 18 proteins associated with systemic lupus erythematosus that were commonly expressed in both control and allergic mice after AgNP exposure. Significant allergy responses were observed after AgNP exposure in control and allergic mice, as determined by ovalbumin-specific immunoglobulin E.

Conclusion: Inhaled AgNPs may regulate immune responses in the lungs of both control and allergic mice. Our results suggest that immunology is a vital response to AgNPs.

Keywords: bronchoalveolar lavage, immunotoxicology, proteome, systemic lupus erythematosus, serum

\section{Introduction}

Silver nanoparticles (AgNPs) are clusters of silver atoms with at least one dimension measuring $<100 \mathrm{~nm}$. AgNPs have antibacterial and antimicrobial properties that are advantageous for applications in medicine. Therefore, AgNPs are increasingly utilized substrates that have been highly commercialized. For example, clothing industries have added AgNPs into fabrics used to make socks, exploiting the antibacterial activity to neutralize odor-forming bacteria. ${ }^{1}$ AgNPs have also been integrated into plastics and surface coatings. Recently, AgNPs have been investigated for treating asthma;,2,3 however, the effects of AgNP inhalation on healthy and asthmatic individuals are unclear.

The potential for nanomedicine in allergen immunotherapy is currently being investigated and developed. AgNPs are candidates for the treatment of allergic asthma. ${ }^{2,3}$ AgNPs have larger surface area-to-volume ratios for interacting with bacteria and lower toxicity than other metal nanoparticles (NPs). ${ }^{4}$ A recent study of the immunology of AgNPs suggested that they have significant adjuvant effects and 
that the mechanism of these effects is the recruitment and activation of local leukocytes, especially macrophages. ${ }^{5}$ Park et al observed that AgNPs might have an antioxidant effect by attenuating antigen-induced airway inflammation and hyperresponsiveness. ${ }^{2}$ Further, AgNPs suppressed mucus hypersecretion and the vascular endothelial growth factor signaling pathway during allergic airway inflammation. ${ }^{3}$ However, biological applications employing AgNPs should be thoroughly studied for potential negative side effects. ${ }^{6,7}$

Toxicoproteomics is increasingly applied to discover diagnostic biomarkers of human disease, for example, lung cancer. ${ }^{8}$ A "protein biomarker" is a protein or peptide that can be objectively and quantitatively measured and evaluated as an indicator of normal or pathological biological processes, exposure to environmental factors, lifestyle factors, the presence of pathogens, or responsiveness to a therapeutic intervention. In this regard, bronchoalveolar lavage fluid (BALF) and blood samples may be used to measure biomarkers for several purposes, including diagnosis, screening, evaluation of risk or predisposition, assessment of prognosis, or surrogate markers. ${ }^{9}$ Several techniques have been developed for proteomic research. For example, two-dimensional gel electrophoresis is commonly used to identify unique protein expression profiles in biological samples. Mass spectrometry for protein identification has been successfully utilized in a number of toxicology studies. Further, gas-phase fractionation is an iterative mass spectrometry approach that examines multiple smaller mass-to-charge ranges. This process enables the ions selected for collision-induced dissociation to come from a greater number of unique peptides compared with the ions selected from the wide mass range scan in automated liquid chromatography-tandem mass spectrometry analysis. ${ }^{10,11}$ Proteomics approaches are becoming more popular in clinical medicine and environmental toxicology.

Inflammation, thrombosis and coagulation, and vascular function and heart rate variability are the human pathophysiological responses to particulate pollution exposure. ${ }^{12}$ However, there is no standard guidance for AgNP inhalation exposure. Nonetheless, the protein profiles in body fluids and their biological pathways following AgNP exposure remain unclear. The objective of this study was to investigate the protein profiles and potential biological pathway in biological fluids in healthy and allergic subjects using proteomic analyses. We established an ovalbumin (OVA)-sensitized allergic mouse model to evaluate the allergenicity of AgNPs in healthy and susceptible mice. The animals inhaled AgNPs that were generated by an evaporation-condensation method. After AgNP inhalation, the BALF and plasma protein profiles were identified in allergic and healthy mice. Finally, we analyzed the biological processes, protein functional classifications, and pathways based on the identified proteins.

\section{Materials and methods}

\section{Animals}

Female 6-week-old BALB/c mice were obtained from BiOLASCO (Taipei, Taiwan). The mice were maintained at a constant temperature and a relative humidity of $22^{\circ} \mathrm{C} \pm 2{ }^{\circ} \mathrm{C}$ and $55 \% \pm 10 \%$, respectively; a light-dark cycle (12-12 hours) was used throughout the study. The animals were housed in plastic cages and were provided the Lab Diet 5001 (PMI Nutrition International, St Louis, MO, USA) and water ad libitum during acclimatization and pre- and post-exposure. The animal experiments were performed in compliance with the animal and ethics review committee of the Laboratory Animal Centre at the National Taiwan University (Taipei, Taiwan).

\section{AgNP generation and characterization}

An evaporation-condensation method was used to generate AgNPs, as described previously. ${ }^{13,14}$ In brief, silver powder (>99\%, Merck KGaA, Darmstadt, Germany) was evaporated at the centre of a $1,100^{\circ} \mathrm{C}$ tube furnace (model T11-301, SJ Ltd, Taipei, Taiwan), and the generated silver vapor was transported continuously using nitrogen at a flow rate of $6 \mathrm{~L} /$ minutes. Because the furnace outlets were equipped with a chilling system, the silver vapor was quenched suddenly and condensed to form AgNPs. In this study, an additional condition section was introduced between the generation system and the exposure chamber to guarantee that the temperature, relative humidity, and composition of the exposed AgNP stream were close to the constant environmental conditions. The oxygen and nitrogen air (5 L/minute at a flow rate of 1:1) was delivered and mixed with the exposed AgNP stream. Next, the exposed AgNP stream was split into two routes for filtration with or without high-efficiency particulate air filters before its introduction into whole-body exposure chambers, which have been described previously. ${ }^{15}$

A TSI Scanning Mobility Particle SizerTM Spectrometer 3936 with nano-differential mobility analyzer (DMA) (TSI Incorporated, Shoreview, MN, USA) was used to continuously monitor the size distribution of AgNPs in the exposure chamber throughout the entire exposure period. The flow rates of the aerosol stream and sheath air of the 
scanning mobility particle sizer were fixed at 0.3 and $3.0 \mathrm{~L} /$ minute, respectively. The scanning mobility particle sizer was calibrated with $100 \mathrm{~nm}$ National Institute of Standards and Technology-traceable polystyrene latex spheres standard particles before the experiment. The total particle number concentrations, the number-based geometric mean diameter, and the geometric standard deviation were recorded. To physicochemically characterize the generated AgNPs, AgNPs were collected onto $37 \mathrm{~mm}$ Teflon substrates (Merck Millipore, Darmstadt, Germany), quarters of which were fixed onto $13 \mathrm{~mm}$ aluminum scanning electron microscopy (SEM) stubs. ${ }^{16}$ The samples were platinum-coated to an average thickness of $10 \mathrm{~nm}$ using a sputter coater and were imaged using an Inspect ${ }^{\mathrm{TM}}$ SEM (FEI, Hillsboro, OR, USA) at an accelerating voltage of $3 \mathrm{kV}$ and a spot size of 2.5 .

Inductively coupled plasma mass spectrometry (ICP-MS; Elan 500, PerkinElmer, Waltham, MA, USA) was used to determine any contamination in the AgNPs. These samples were digested with concentrated nitric acid (Fisher Primar grade, specific gravity 1.48; Thermo Fisher Scientific, Waltham, MA, USA) carried out in a CEM MDS-2000 microwave digestor oven (CEM, SpectraLab Scientific Inc, Markham, ON, Canada), using CEM advanced Teflon-lined composite vessels. ${ }^{17}$ The pressure was increased to 80 pounds per square inch for approximately 20 minutes, producing a digestion temperature of approximately $180^{\circ} \mathrm{C}$. Samples were diluted to $10 \%$ nitric acid using deionized $(>18 \mathrm{M} \Omega$ ) water. Nitric acid blanks were run to detect any contamination during the analysis process. A solution of a certified rock standard (BCR1) was used to check the accuracy of the analyses.

\section{Allergic sensitization, AgNP inhalation, and OVA challenge}

To assess the allergenicity of AgNPs, we used endotoxinfree OVA (Sigma-Aldrich, St Louis, MO, USA) as an allergen to induce systemic sensitization. The procedure used to develop allergic airway disease in mice after AgNP exposure was modified from a published method. ${ }^{18}$ The experimental design is shown in Figure 1. Mice were divided into four groups (control groups 1 and 2 and allergy groups 3 and 4 [OVA]). Group 1 and 3 mice were exposed to highefficiency particulate air filtered air (FA; $n=5$ each group), whereas Group 2 and 4 were exposed to AgNPs ( $n=6$ each group). On Day 0, the mice in the allergic groups received an intraperitoneal injection of $50 \mu \mathrm{g}$ OVA in aluminum hydroxide adjuvant prepared in phosphate-buffered saline (PBS), whereas those in the control groups received the same volume of adjuvant prepared in PBS alone. On Day 8,

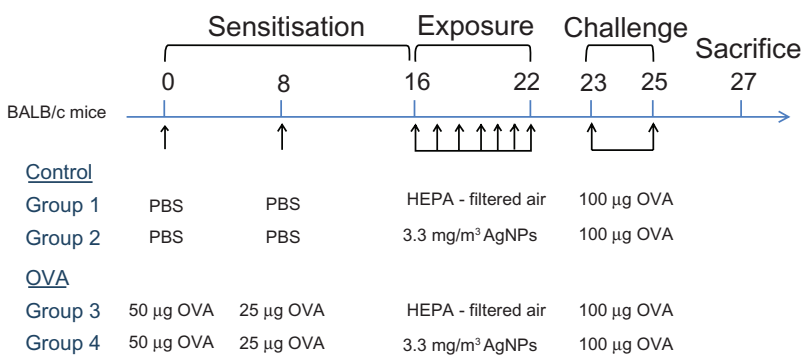

Figure I Experimental design for investigating the effects of silver nanoparticles (AgNPs) on the allergic response to ovalbumin (OVA) antigen using proteomic approaches. OVA: OVA in aluminum hydroxide adjuvant prepared in phosphatebuffered saline (PBS); PBS (control): aluminum hydroxide adjuvant prepared in PBS. Abbreviation: HEPA, high-efficiency particulate air.

the mice in the allergic groups received an intraperitoneal injection of $25 \mu \mathrm{g}$ OVA in aluminum hydroxide adjuvant prepared in PBS, whereas the control groups received the same volume of adjuvant prepared in PBS alone. The mice in the control groups demonstrated a significantly lower level of OVA-specific immunoglobulin (Ig) E than the mice sensitized with OVA $(P<0.001)$. On Day 16 , the allergic and control mice were exposed to $33 \mathrm{~nm} \mathrm{AgNPs}$ ( $3.3 \pm 0.7 \mathrm{mg} / \mathrm{m}^{3}$; Groups 2 and 4) and FA (Groups 1 and 3) in the whole-body chambers for 7 days (6 hours/day, from Day 16 to 22). The mice were challenged intranasally with $100 \mu \mathrm{g}$ OVA between Days 23 and 25, and the animals were euthanized on Day 27.

\section{Animal necropsy and sample collection}

Animal necropsy, and BALF and blood collections were performed as described previously. ${ }^{19}$ Facial vein blood collection was performed before euthanasia. For BALF collection, animals were euthanized with a single intraperitoneal injection of sodium pentobarbitone $(200 \mathrm{mg} / \mathrm{mL})$. A single $0.1 \mathrm{~mL}$ volume of PBS was used to lavage the lungs. All samples were centrifuged at $1,500 \times g$ for 5 minutes at $4^{\circ} \mathrm{C}$ and the cell pellet was removed. For proteomic analyses, $0.5 \mathrm{~mL}$ of BALF or a plasma sample from each group was pooled together following protein preparation.

\section{Trichloroacetic acid precipitation}

The BALF samples were diluted in $120 \mu \mathrm{L}$ dd- $\mathrm{H}_{2} \mathrm{O}$, dried with a SpeedVac concentrator (Thermo Scientific, Asheville, $\mathrm{NC}, \mathrm{USA}$ ), denatured and reduced with $1 \%$ sodium dodecyl sulfate $/ 10 \mathrm{mM}$ dithiothreitol (Sigma-Aldrich) at $95^{\circ} \mathrm{C}$ for 5 minutes and alkylated with $50 \mathrm{mM}$ iodoacetamide (SigmaAldrich) in the dark at room temperature for 30 minutes. Trichloroacetic acid (Sigma-Aldrich) was added to a final concentration of $20 \%$. The mixture was incubated for 
15 minutes on ice and then centrifuged at 13,000 rpm for 10 minutes. The supernatant was removed. The pellet was washed once with $10 \%$ trichloroacetic acid and three times with dd- $\mathrm{H}_{2} \mathrm{O}$ then it was centrifuged at 13,000 rpm for another 5 minutes. Again the supernatant was removed, and then the pellet was digested with trypsin in $25 \mathrm{mM}$ ammonium bicarbonate (Sigma-Aldrich) at $37^{\circ} \mathrm{C}$ for 18 hours.

\section{Protein digestion}

Plasma samples $(2.5 \mu \mathrm{L})$ were diluted to $1 \mathrm{~mL}$ with $50 \mathrm{mM}$ ammonium bicarbonate. Samples were denatured and reduced with $8 \mathrm{M}$ urea/10 $\mathrm{mM}$ dithiothreitol at $37^{\circ} \mathrm{C}$ for 1 hour and alkylated with $50 \mathrm{mM}$ iodoacetamide in the dark at room temperature for 30 minutes. Samples were digested with trypsin in $25 \mathrm{mM}$ ammonium bicarbonate at $37^{\circ} \mathrm{C}$ for 18 hours and then desalted using C18 columns.

\section{Mass spectrometry and protein identification}

The tryptic peptides were analyzed with a $\mathrm{Q}$ Exactive mass spectrometer (Thermo Fisher Scientific) coupled with a Dionex UltiMate ${ }^{\circledR} 3000$ Rapid Separation LC system (Thermo Fisher Scientific). Peptide separation was performed by liquid chromatography with C18 columns (Dionex Acclaim ${ }^{\circledR}$ PepMap $^{\text {TM }}$ RSLC, $75 \times 150$ mm, $2 \mu \mathrm{m}$; Thermo Fisher Scientific) with the following conditions: linear gradient from $1 \%$ to $40 \%$ of Mobile phase B (Mobile phase A: $5.0 \%$ acetonitrile $/ 0.1 \%$ formic acid, Mobile phase B: $95.0 \%$ acetonitrile $/ 0.1 \%$ formic acid) for 55 minutes and then $40 \%-90 \%$ of Mobile phase B for 5 minutes, with a 90-minute separation time. Full mass spectrometry (MS) scans were performed with ranges of $\mathrm{m} / \mathrm{z} 380-2,000, \mathrm{~m} / \mathrm{z}$ $380-600, m / z 600-800, m / z$ 800-1,200, and $m / z$ 1,200-2,000, and the ten most intense ions from MS scans were selected for MS/MS scans. Raw data were processed into peak lists by Proteome Discoverer (v 1.3; Thermo Scientific) for Mascot database search (http://www.matrixscience.com/ search form select.html) with the National Centre for Biotechnology Information and UniProt database prediction and literature search. Search parameters included variable modifications for deamidation (NQ), oxidation (M), and fixed modification for carbamidomethyl $(\mathrm{C})$. The maximum mass tolerance was set to $10 \mathrm{ppm}$ for precursor ions and $0.05 \mathrm{Da}$ for fragment ions.

\section{Protein functional analyses}

The expressed BALF and plasma proteins (Group 1 vs Group 3 and Group 2 vs Group 4) were analyzed with the
Protein ANalysis THrough Evolutionary Relationships (PANTHER) Classification System (http://www.pantherdb. org/) and the Database for Annotation, Visualization and Integrated Discovery (DAVID) gene functional analysis tools (http://david.abcc.ncifcrf.gov/) to better understand the biological context of the identified proteins, their connection to disease pathology, and their participation in physiological pathways. ${ }^{20,21}$ The UniProt accession database was used to access the 19 overlapping BALF proteins (between Group 1 vs Group 3 and Group 2 vs Group 4) identified in this study. These proteins were uploaded and mapped against the Mus musculus reference dataset to extract and summarize the functional annotation associated with individual genes/proteins or groups of genes/proteins and to identify the gene ontology terms, biological processes, functional classification, and important pathways for each dataset.

\section{Determination of OVA-specific lgE}

The plasma OVA-specific IgE levels before (on Day 15) and after (on Day 23) AgNP exposure and OVA challenge were measured using Mouse IgE ELISA Set (BD Biosciences San Jose, CA, USA) in accordance with the manufacturer's instructions.

\section{Results}

\section{Characterization of AgNPs}

AgNPs were generated by the evaporation-condensation method and were physicochemically characterized by SEM. Spherical AgNPs with an average size of $33 \mathrm{~nm}$ and a total mass of $3.3 \pm 0.7 \mathrm{mg} / \mathrm{m}^{3}$ were produced, and the vast majority of these rapidly aggregated to form clusters (Figure 2). ICP-MS data from filters with and without AgNPs demonstrated the production of Ag-containing NPs. The ICP-MS results also excluded the possibility of impurities or contaminants introduced to the AgNPs during their generation.

\section{Proteomic profile of BALF}

To identify the proteins expressed after AgNP exposure, the overlaps in protein profiles between FA and AgNP inhalation in control (Figure 3A) and allergy groups were compared (Figure 3A). There were 169 proteins identified in FA-exposed control mice, whereas 220 proteins were determined in AgNP-exposed control mice. There were 114 common proteins in control mice exposed to FA or AgNP. Therefore, 55 and 106 proteins were unique for FA and AgNP, respectively. We further analyzed the 106 unique AgNP-associated proteins in the control BALF 

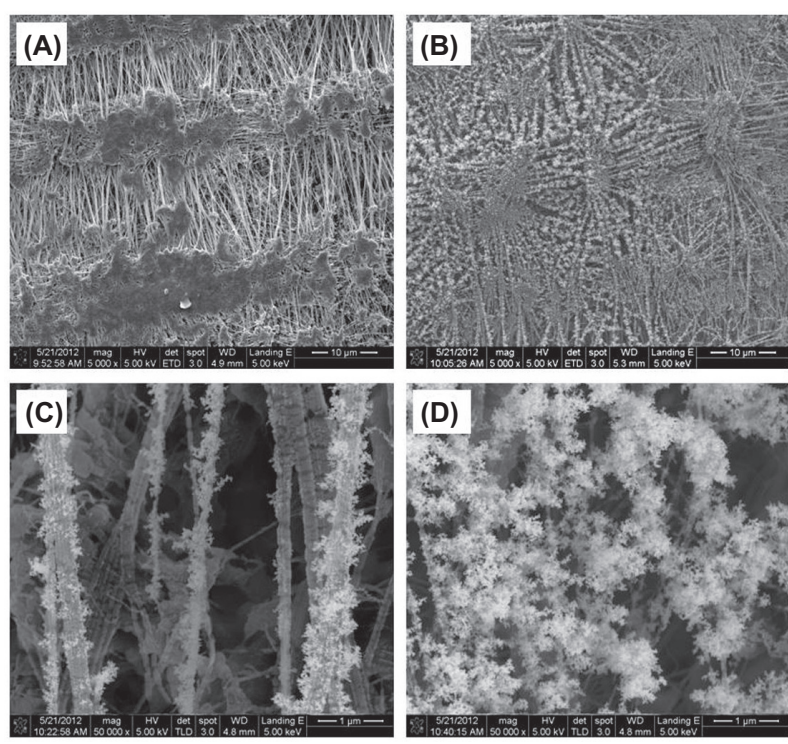

Figure 2 Scanning electron microscopy images of $(\mathbf{A})$ the blank Teflon substrate and (B) silver nanoparticles (AgNPs) collected on the Teflon substrate at 5,000 $\times$ and (C and D) 50,000× magnification.

samples (Table S1). Similarly, 151 and 211 proteins were identified in allergic mice after FA and AgNP exposure, respectively. Because there were 132 common proteins expressed after FA or AgNP exposure, there were 19 and 79 proteins unique to FA and $\mathrm{AgNP}$ exposure, respectively.
(A)

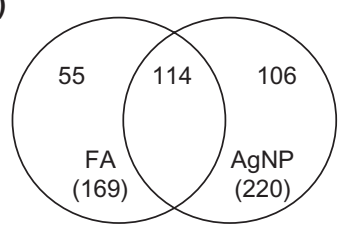

(C)

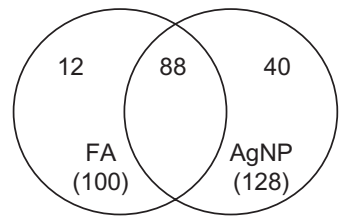

(E)

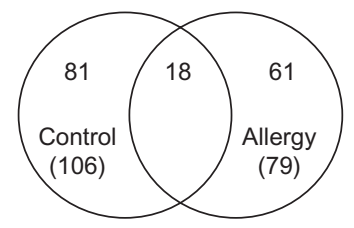

(B)

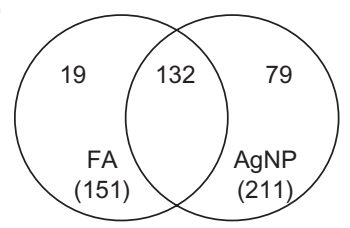

(D)

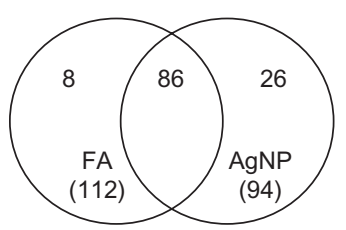

(F)

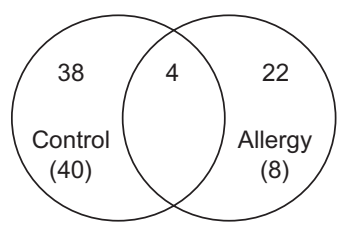

Figure 3 Venn diagrams showing the proteins common or unique to silver nanoparticle (AgNP) treatment. (A) Bronchoalveolar lavage fluid (BALF) proteins in control mice, (B) BALF proteins in allergic mice, (C) plasma proteins in control mice, and (D) plasma proteins in allergic mice. The identified AgNP-unique proteins were further analyzed for commonalities in control and allergic mice after AgNP exposure. (E) Proteins commonly expressed in BALF and (F) proteins commonly expressed in plasma.

Abbreviation: FA, filtered air.
The 79 unique AgNP-associated proteins in the allergic BALF samples were further analyzed (Table S2).

MS-based functional pathway analyses were performed with the BALF proteins in control and allergy groups to understand their biological context. PANTHER analysis was initially used to examine the protein functions in biological processes (Figure 4). These proteins were associated with 15 biological processes (Figure 4A): cell communication (11.4\% for control and $10.2 \%$ for allergy), cellular processes (15.7\% for control and $14.1 \%$ for allergy), transport (5.0\% for control and $9.4 \%$ for allergy), cellular component organization ( $4.3 \%$ for control and $5.5 \%$ for allergy), apoptosis ( $0.7 \%$ for control and $3.1 \%$ for allergy), system processes (5.7\% for control and $4.7 \%$ for allergy), stimulus response (9.3\% for control and $7.8 \%$ for allergy), developmental processes $(8.6 \%$ for control and $8.6 \%$ for allergy), metabolic processes (18.6\% for control and $17.2 \%$ for allergy), cell cycle ( $2.1 \%$ for control and $3.9 \%$ for allergy), immune system processes (11.4\% for control and $10.9 \%$ for allergy), cell adhesion (3.6\% for control and $4.7 \%$ for allergy), reproduction ( $1.4 \%$ for control only), homeostatic processes $(0.7 \%$ for control only), and the generation of precursor metabolites and energy ( $1.4 \%$ for control only). Metabolic, cellular, and immune system processes and cell communication were the critical biological processes that were modulated in response to AgNP exposure in both control and allergic mice, as determined by BALF analysis.

Functional pathways were further investigated using PANTHER analysis (Figure 5). The AgNP-unique proteins in the control and allergy groups were involved in 12 pathways, including those mediating blood coagulation, integrin signaling, ubiquitin proteasomes, inflammation resulting from chemokine and cytokine signaling, T-cell activation, tricarboxylic acid cycle, dopamine receptormediated signaling, plasminogen activating cascade, Fas signaling pathway, cytoskeletal regulation by Rho GTPase, nicotine pharmacodynamics, and nicotinic acetylcholine receptor signaling.

\section{Proteomic profile of plasma}

The protein profiles in plasma after FA and AgNP inhalation by control (Figure 3C) or allergy groups were compared (Figure 3D). We identified 100 proteins expressed in FA-exposed control mice and 128 in AgNP-exposed control mice; there were 88 proteins common to both control exposures. There were 12 and 40 proteins unique to FA and AgNP, respectively. We used the 40 unique AgNPassociated proteins in the control BALF samples for further 

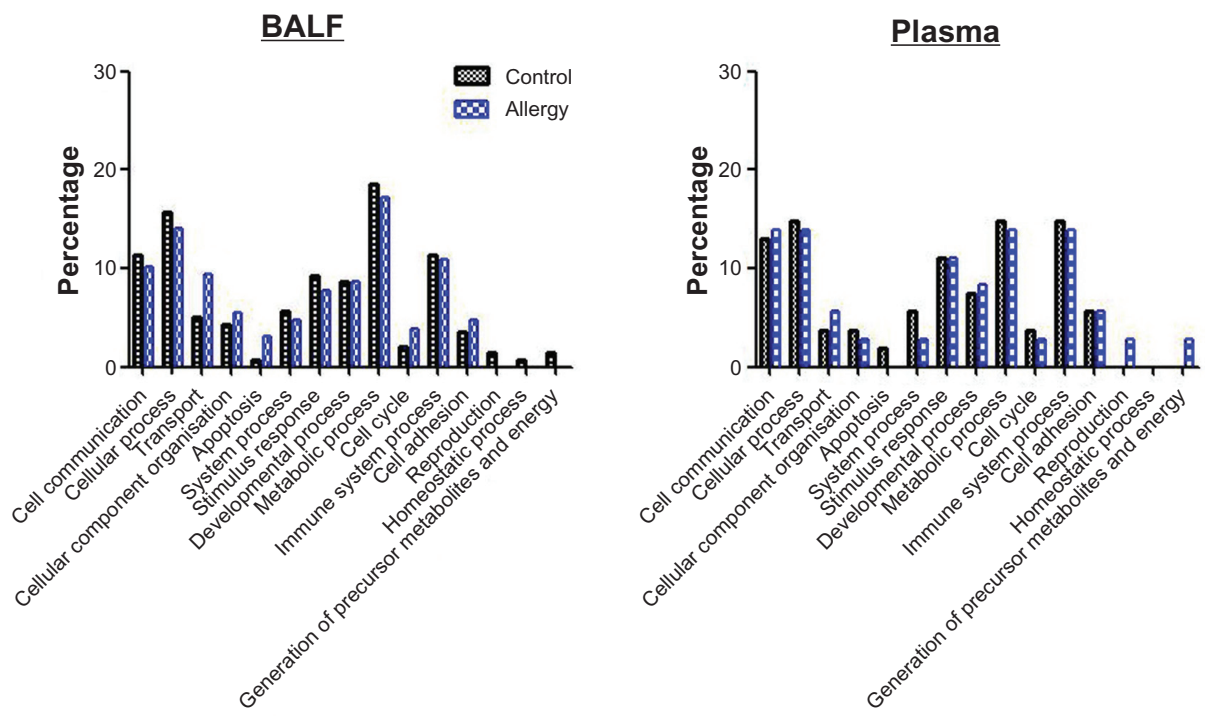

Figure 4 Biological process in (A) bronchoalveolar lavage fluid (BALF) and (B) plasma obtained using Protein ANalysis THrough Evolutionary Relationships (PANTHER) analysis.

analyses (Table S3). Additionally, there were 112 and 94 proteins identified in allergic mice after FA or AgNP exposure, respectively, 86 of which were shared by both groups. There were eight and 26 proteins uniquely expressed after FA and AgNP exposure, respectively. The 26 unique AgNP-associated proteins in the allergic BALF samples were further analyzed (Table S4).

PANTHER analysis was used to examine the protein functions in biological processes (Figure 4). These proteins were associated with 14 biological processes (Figure 4B): cell communication $(13.0 \%$ for control and $13.9 \%$ for allergy), cellular processes (14.8\% for control and $13.9 \%$ for allergy), transport (3.7\% for control and 5.6\% for allergy), cellular component organization (3.7\% for control and $2.8 \%$ for allergy), apoptosis (1.9\% for control only), system processes (5.6\% for control and $2.8 \%$ for allergy), stimulus response (11.1\% for control and $11.1 \%$ for allergy), developmental processes ( $7.4 \%$ for control and $8.3 \%$ for allergy), metabolic processes $(14.8 \%$ for control and $13.9 \%$ for allergy), cell cycle (3.7\% for control and $2.8 \%$ for allergy), immune system processes $(14.8 \%$ for control and $13.9 \%$ for allergy), cell adhesion (5.6\% for control and $5.6 \%$ for allergy), reproduction ( $2.8 \%$ for allergy only) and the generation of precursor metabolites and energy $(2.8 \%$ for
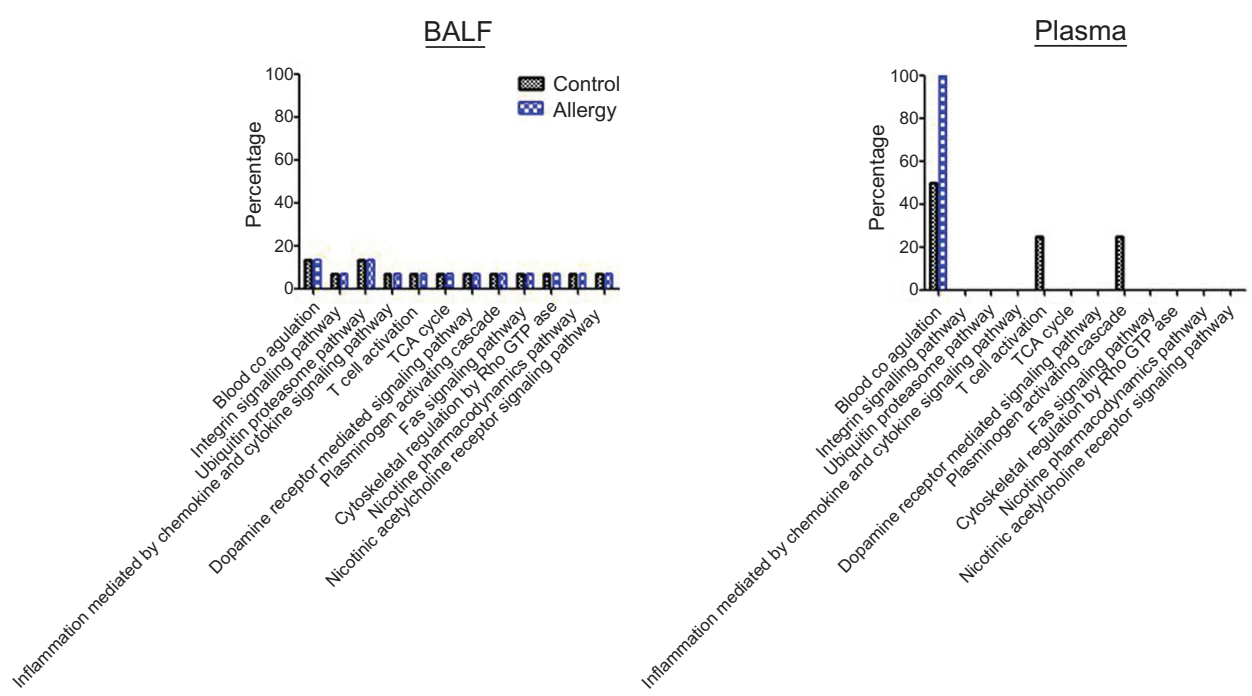

Figure 5 Pathway analysis in (A) bronchoalveolar lavage fluid (BALF) and (B) plasma protein using Protein ANalysis THrough Evolutionary Relationships (PANTHER) analysis.

Abbreviation: TCA cycle, tricarboxylic acid cycle. 
allergy only). Cellular, metabolic, and immune system processes and stimulus response were important biological processes that were modulated in response to AgNP exposure in both control and allergic mice, as determined by plasma analysis.

Pathway analysis was performed using PANTHER (Figure 5). Three pathways - blood coagulation, T-cell activation, and plasminogen activating cascade - were determined based on the AgNP-unique proteins in control groups. Notably, blood coagulation was only found in the allergy group.

\section{Functional pathway analyses of BALF and plasma proteins}

To determine the common proteins induced by AgNP exposure in control and allergy groups, the unique AgNPassociated proteins in BALF (Figure 3E) and serum (Figure 3F) were compared. There were 18 overlapping proteins in BALF (Table 1): apolipoprotein E, myosin light polypeptide 6 , heterogeneous nuclear ribonucleoproteins A2/B1, transitional endoplasmic reticulum ATPase, Ig alpha chain $\mathrm{C}$ region, Ig heavy chain $\mathrm{V}$ region MOPC 47A,
Ig heavy chain V region 441, histone $\mathrm{H} 4$, glyoxalase domain-containing protein 4 , extracellular superoxide dismutase $(\mathrm{Cu}-\mathrm{Zn})$, Ig lambda-1 chain $\mathrm{C}$ region, annexin A2, inter-alpha-trypsin inhibitor heavy chain $\mathrm{H} 2$, myosin regulatory light polypeptide 9, histone H2A type 1-F, heat shock $70 \mathrm{kDa}$ protein 4 , vimentin, and proteasome subunit alpha type-1. Further, there were four overlapping proteins in plasma (Table 1): carboxypeptidase $\mathrm{N}$ subunit 2, zincalpha-2-glycoprotein, vasohibin-1, and interleukin-1 receptor accessory protein.

DAVID analysis revealed functional classifications, including heterotetramer $\left(P=3.9 \times 10^{-5} ; 27 \%\right)$, immunoglobulin v region $\left(P=7.7 \times 10^{-4} ; 20 \%\right)$, acetylation $\left(P=9.4 \times 10^{-4} ; 53 \%\right)$, immunoglobulin $\left(P=9.5 \times 10^{-4}\right.$; $20 \%)$, immunoglobulin domain $\left(P=4.5 \times 10^{-3} ; 27 \%\right)$, immunoglobulin c region $\left(P=8.6 \times 10^{-3} ; 13 \%\right)$, phosphoprotein $\left(P=7.9 \times 10^{-2} ; 60 \%\right)$, duplication $\left(P=9 \times 10^{-2} ; 13 \%\right)$ and secretion $\left(P=9.4 \times 10^{-2} ; 27 \%\right)$. Further, the overlapping unique AgNP-associated proteins were associated with systemic lupus erythematosus $\left(P=6.8 \times 10^{-3} ; 13 \%\right)$. For the plasma samples, analysis of functional classification showed that the overlapping unique AgNP-associated

Table I Silver nanoparticle-unique proteins expressed in mice sensitized with phosphate-buffered saline (control) or ovalbumin (allergy)

\begin{tabular}{|c|c|c|c|c|c|}
\hline No & Name of protein with UniProt accession number & $\begin{array}{l}\text { Mascot* } \\
\text { score }\end{array}$ & $\begin{array}{l}\text { Calculated Mw } \\
\text { (Dalton) }\end{array}$ & $\begin{array}{l}\text { Sequence } \\
\text { covered } \%\end{array}$ & Calculated pl \\
\hline \multicolumn{6}{|c|}{ BALF } \\
\hline I & Apolipoprotein E (P08226) & 134 & 35,901 & 12.9 & 5.56 \\
\hline 2 & Myosin light polypeptide 6 (P60660) & 91 & 17,090 & 16.6 & 4.56 \\
\hline 3 & Heterogeneous nuclear ribonucleoproteins A2/BI (O88569) & 89 & 37,437 & 6.2 & 8.97 \\
\hline 4 & Transitional endoplasmic reticulum ATPase (P55072) & 78 & 89,950 & 4.6 & 5.14 \\
\hline 5 & Ig alpha chain C region (P0I878) & 69 & 37,594 & 4.4 & 4.97 \\
\hline 6 & Ig heavy chain $\mathrm{V}$ region MOPC $47 \mathrm{~A}$ (P0I786) & 60 & $|3,08|$ & 13.7 & 8.99 \\
\hline 7 & Ig heavy chain $\mathrm{V}$ region $44 \mathrm{I}$ (P0I806) & 56 & 13,074 & 13.8 & 8.46 \\
\hline 8 & Histone H4 (P2067I) & 56 & 11,360 & 9.7 & 11.36 \\
\hline 9 & Glyoxalase domain-containing protein 4 (Q9CPV4) & 51 & 33,581 & 6.0 & 5.28 \\
\hline 10 & Extracellular superoxide dismutase (Cu-Zn) (O09I64) & 50 & 27,717 & 5.6 & 6.36 \\
\hline II & Ig lambda-I chain C region (P0 I843) & 49 & II,739 & 32.4 & 5.87 \\
\hline 12 & Annexin A2 (P07356) & 48 & 38,937 & 3.2 & 7.55 \\
\hline 13 & Inter-alpha-trypsin inhibitor heavy chain H2 (Q6I703) & 48 & 106,261 & 1.6 & 6.82 \\
\hline 14 & Myosin regulatory light polypeptide 9 (Q9CQ19) & 47 & 19,898 & 5.2 & 4.80 \\
\hline 15 & Histone H2A type I-F (Q8CGP5) & 45 & 14,153 & 6.9 & 11.05 \\
\hline 16 & Heat shock 70 kDa protein 4 (Q6I3।6) & 42 & 94,872 & 1.7 & 5.15 \\
\hline 17 & Vimentin (P20I52) & 36 & 53,712 & 2.4 & 5.06 \\
\hline 18 & Proteasome subunit alpha type-I (Q9RIP4) & 36 & 29,813 & 4.9 & 6.00 \\
\hline \multicolumn{6}{|c|}{ Plasma } \\
\hline I & Carboxypeptidase N subunit 2 (Q9DBB9) & 61 & 61,296 & 2.9 & 5.53 \\
\hline 2 & Zinc-alpha-2-glycoprotein (Q64726) & 45 & 35,538 & 5.9 & 5.83 \\
\hline 3 & Vasohibin-I (Q8CIWI) & 32 & 42,020 & 2.9 & 9.42 \\
\hline 4 & Interleukin-I receptor accessory protein (Q6I730) & 31 & 66,383 & 1.8 & 7.85 \\
\hline
\end{tabular}

Notes: Eighteen proteins in bronchoalveolar lavage fluid (BALF) and four proteins in plasma were identified. *Matrix Science, Boston, MA, USA. Abbreviation: Ig, immunoglobulin. 
proteins were secreted peptides $\left(P=5 \times 10^{-4} ; 100 \%\right)$ and signaling molecules $\left(P=7.2 \times 10^{-2} ; 75 \%\right)$. However, there was no pathway identified by these overlapping unique AgNP-associated proteins in plasma.

\section{Determination of OVA-specific lgE}

AgNP inhalation induced significant allergic responses in both control and allergy groups, as determined by the plasma levels of OVA-specific IgE in samples collected 2 days after OVA challenge $(P<0.05$, Figure 6$)$. There was no significant difference in the plasma levels of OVAspecific IgE in control and allergy groups before and after FA exposure. OVA-specific IgE levels were 1.3 times higher in control mice and 14.3 times higher in allergic mice after AgNP exposure.

\section{Discussion}

BALF and plasma are important biological fluids containing diverse proteins released by dysfunctional cells and injured tissues. BALF and plasma proteomics are of considerable interest for toxicological and clinical studies, particularly in disease biomarker discovery. ${ }^{22,23} \mathrm{~A}$ "protein biomarker" is a protein or peptide that can be objectively and quantitatively measured and evaluated as an indicator of normal or pathological biological processes or exposure to environmental factors. This study used proteomics to determine the allergenicity of AgNPs, generated using the evaporation-condensation method, in allergen provoked murine models. We found 106 and 79 unique

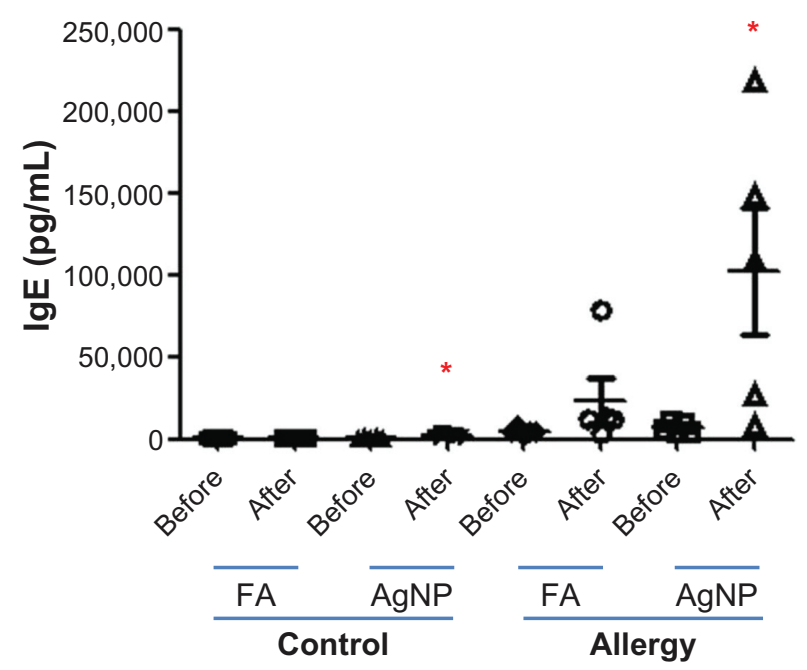

Figure 6 Ovalbumin (OVA)-specific immunoglobulin (Ig) E was collected from control and allergic mice I day before and 2 days after silver nanoparticle (AgNP)/ filtered air (FA) inhalation and OVA challenge.

Note: Values are expressed as the means \pm standard deviation; $n=5-6$. $* P<0.05$.
AgNP-associated proteins in BALF from control and allergic mice, respectively, after AgNP inhalation. Additionally, 40 and 26 unique AgNP-associated proteins were found in the plasma of control and allergic mice, respectively. The BALF and plasma protein profiles suggested that metabolic, cellular, and immune system processes were modulated in response to AgNP pulmonary exposure. The inhaled AgNPs may regulate immune responses in the lungs of control and allergic mice, as the overlapping unique AgNP-associated proteins in BALF (18 proteins) have also been associated with systemic lupus erythematosus. Further, significant allergy responses were observed after AgNP exposure in control and allergic mice, as determined by OVA-specific IgE.

We investigated the allergenicity of AgNPs in the lungs of mice. The pulmonary toxicity of airborne materials is commonly evaluated by inhalation exposure in animals. These models mimic the natural route of entry into the host and, as such, are the preferred method for the introduction of toxicants into the lungs. ${ }^{24}$ Toxicokinetics and inhalation studies are important methods used to measure the hazards associated with AgNP exposure. In this study, AgNPs were produced by the evaporation-condensation method, and the allergic responses in mice after AgNP inhalation were determined. The advantage of this procedure is that AgNPs can be generated continuously and stably for longterm inhalation at a range of levels, reflecting the natural exposure route for respirable NPs rather than exposure via intratracheal instillation or pulmonary aspiration. Pure silver powder was evaporated at $1,100^{\circ} \mathrm{C}$ and the vapor was quenched immediately, resulting in spherical AgNPs. Using SEM and ICP-MS, uncontaminated spherical AgNPs were generated by this method. Our results are in line with those of a previous study, ${ }^{25}$ suggesting that the AgNPs could associate with physically bonded (ie, agglomerate) and chemically or sinter-bonded (aggregate) structures. The AgNP aggregate, with a size of $33 \mathrm{~nm}$, was easily inhaled deep into the lungs and interacted with the epithelial cells.

Proteomic analyses of biological fluids are very effective for studying pathogen- or other stimulus-induced alterations in hosts and to host responses. ${ }^{26} \mathrm{We}$ investigated the protein profiles in BALF and plasma after AgNP inhalation by healthy (control) and diseased (OVA-sensitized allergy) mouse models. The gas-phase fractionation method was used to increase proteome coverage and the reproducibility of peptide ion selection by direct MS analysis of the peptides produced by proteolytic digestion of unfractionated proteins from the BALF and plasma samples. ${ }^{8} 10$ Using the gasphase fractionation method, we demonstrated that AgNPs 
induced expression of 106 unique proteins in healthy mice and 79 unique proteins in OVA-sensitized mice. Protein identifications have been published previously. ${ }^{8,27}$ Inhaled NPs first interact with the lung epithelial lining fluid, which induces a rapid biological response. PANTHER analysis identified four major biological processes associated with AgNP exposure in the BALF of control and allergic mice: metabolic, cellular, and immune system processes and cell communication. A previous study exposed Sprague Dawley rats in whole-body exposure chambers to environmental cigarette smoke for 28 days. Environmental cigarette smoke stimulated 56 proteins in lung tissues, including those involved in the stress response, protein removal, cell replication, apoptosis, phagocytosis, and the immune response. ${ }^{28} \mathrm{~A}$ recent study observed that AgNPs have significant immunological adjuvant effects in BALB/c mice. ${ }^{5}$ Additionally, Kang et a ${ }^{29}$ demonstrated that ultrafine ambient particles are adjuvants that enhance allergic inflammation in BALB/c mice. Expression of polymeric immunoglobulin receptor, complement $\mathrm{C} 3$, neutrophil gelatinase-associated lipocalin, chitinase 3-like protein 3, chitinase 3-like protein 4 , and acidic mammalian chitinase was altered in BALF after particle exposure. To compare the differences in biological processes after pulmonary exposure to AgNPs and ambient particles, in the current study, these six BALF proteins were further analyzed with PANTHER. We found that ambient particle exposure induced proteins involved in reproduction (7.7\%), stimulus response (15.4\%), immune system processes (15.4\%), cellular processes $(15.4 \%)$, metabolic processes $(15.4 \%)$, cell communication $(7.7 \%)$, system processes (7.7\%), and transport (15.4\%). A similarity was observed in the biological processes induced by AgNP exposure and ambient particle exposure. Taken together, these data suggest that pulmonary exposure to particulate substances such as AgNPs induced immune responses. The particle's physicochemistry may be a pivotal parameter that determines the severity of immunotoxicology. The physicochemical characteristics of nanoscaled particles contribute to oxidativeinflammatory reactions. ${ }^{30,31}$ We also elucidated the functions of proteins modulated in response to AgNPs in the lung environment; these functional categories included blood coagulation, activation of the integrin signaling pathway and ubiquitin proteasome pathway; inflammation mediation by chemokines; activation of the cytokine signaling pathway; T-cell activation; activation of the tricarboxylic acid cycle, dopamine receptor-mediated signaling pathway, plasminogen activating cascade, and Fas signaling pathway; cytoskeletal regulation by Rho GTPase; and activation of the nicotine pharmacodynamics pathway and nicotinic acetylcholine receptor signaling pathway. AgNP exposure may alter blood coagulation via platelet activation and thrombus formation, ${ }^{32}$ oxidative-inflammatory responses, ${ }^{2,3}$ and innate immune responses..$^{33}$ The mechanisms underlying AgNP-induced pathologies should be investigated.

Additionally, we identified 40 and 26 AgNP-associated proteins in plasma from healthy and allergen-sensitized mice, respectively. PANTHER analysis indicated that the biological processes involved were similar to those in BALF samples, which were categorized as cellular, metabolic, and immune system processes and stimulus responses. Stimulus responses were the major difference between the BALF and plasma samples. Internal and external stimuli can induce biological responses. Previous studies revealed that the inhalation of AgNPs induced oxidative stress and inflammation. ${ }^{3,7}$ AgNPs initiate oxidative imbalance in the form of inflammatory responses. Oxidative stress promotes the influx of inflammatory cells (eg, macrophages and neutrophils) to the lungs, leading to a second wave of systemic oxidative stress and inflammation due to the large quantities of free radicals released from activated inflammatory cells. ${ }^{34}$ Blood coagulation, T-cell activation, and the plasminogen-activating cascade were associated with AgNP inhalation. Comparisons between BALF and plasma proteins suggest that because the lung environment interacts directly with inhaled AgNPs, it is important for initiating several biological pathways. In contrast, plasma samples may represent downstream biological responses to lung stimulation. The association between pulmonary and systemic responses to AgNP exposure requires further investigation.

Alterations in overlapping AgNP-associated proteins in BALF and plasma were also examined. The identified proteins were able to elucidate the common biological processes and pathways in control and allergy subjects. Further, these proteins may be candidates for AgNP-related biomarkers. Our proteomic analysis revealed 18 overlapping proteins in the BALF and four overlapping proteins in plasma. DAVID functional classification software was used to determine the pathway of the proteins identified in BALF and plasma. The proteins found in BALF samples suggest that AgNP exposure is associated with "systemic lupus erythematosus," which is an autoimmune disease characterized by intense polyclonal production of autoantibodies and circulating immune complexes. Environmental pollutants are risk factors for systemic lupus erythematosus. Cigarette smoke, for example, is positively associated with increased risk 
for systemic lupus erythematosus. ${ }^{35}$ Air pollution has been shown to be associated with autoimmune rheumatic disease in humans. ${ }^{36}$ Systemic lupus erythematosus is characterized by a Th2 immune response ${ }^{37}$ and increased $\operatorname{IgE}$ production and is also associated with allergy. ${ }^{37}$ In this study, we observed that OVA-specific IgE levels were significantly increased following AgNP inhalation in control and allergy groups. While these results confirm that immune responses are induced by AgNP exposure, they might also suggest that exposure to AgNPs increases the risk of systemic lupus erythematosus, but this hypothesis requires further investigation.

\section{Conclusion}

Our knowledge of the mechanisms underlying asthma is still limited. As far as we are aware, this study is the first to investigate BALF and plasma protein profiles after pulmonary exposure to AgNPs. Comprehensive proteomic analysis using the gas-phase fractionation method and bioinformatics analyses revealed that several proteins were induced in the BALF and plasma of healthy and allergic mice. Our results suggest that these proteins are associated with various essential physiological processes and biological functions. Further, the BALF proteomic results suggest that immunotoxicology is a pivotal response to AgNPs. One limitation of this study is that the levels of specific proteins were not determined, and these data should be generated in future studies. We suggest that BALF proteomic profiling could be used as an effective approach to screen AgNP adjuvant effects. Our findings may fill the gap between epidemiological and clinical research, but the safety of AgNPs in airway therapeutic strategies should be examined carefully before commercial applications are implemented.

\section{Acknowledgments}

The authors wish to thank Drs Yuan-Horng Yan, Kuo-Liang Huang, Hui-Hsien Chang, and Ta-Chih Hsiao for their technical assistance with this research.

\section{Funding}

This research was a collaboration between Taipei Medical University, Shuang Ho Hospital, and the National Taiwan University. Portions of this work were performed and funded by the Shang Ho Hospital (102 SHH-HCP-16) and Taipei Medical University (grant numberTMU101-AE1-B53). Some of the experimental works were performed in the National Taiwan University and supported by the National Science Council of Taiwan (grant number 101-2621-M-002-004).

\section{Authors' contributions}

All authors have contributed substantially to the concept, design, drafting the article, and critically revising the manuscript for important intellectual content. All authors read and approved the final version of the manuscript for publication.

\section{Disclosure}

The authors declare no conflicts of interest in this work.

\section{References}

1. Benn TM, Westerhoff P. Nanoparticle silver released into water from commercially available sock fabrics. Environ Sci Technol. 2008;42(11): 4133-4139.

2. Park HS, Kim KH, Jang S, et al. Attenuation of allergic airway inflammation and hyperresponsiveness in a murine model of asthma by silver nanoparticles. Int J Nanomedicine. 2010;5:505-515.

3. Jang S, Park JW, Cha HR, et al. Silver nanoparticles modify VEGF signaling pathway and mucus hypersecretion in allergic airway inflammation. Int J Nanomedicine. 2012;7:1329-1343.

4. Foldbjerg R, Olesen P, Hougaard M, Dang DA, Hoffmann HJ, Autrup H. PVP-coated silver nanoparticles and silver ions induce reactive oxygen species, apoptosis and necrosis in THP-1 monocytes. Toxicol Lett. 2009;190(2):156-162.

5. Xu Y, Tang H, Liu JH, Wang H, Liu Y. Evaluation of the adjuvant effect of silver nanoparticles both in vitro and in vivo. Toxicol Lett. 2013;219(1):42-48.

6. Ghosh M, J M, Sinha S, et al. In vitro and in vivo genotoxicity of silver nanoparticles. Mutat Res. 2012;749(1-2):60-69.

7. Mei N, Zhang Y, Chen Y, et al. Silver nanoparticle-induced mutations and oxidative stress in mouse lymphoma cells. Environ Mol Mutagen. 2012;53(6):409-419.

8. Yu CJ, Wang CL, Wang CI, et al. Comprehensive proteome analysis of malignant pleural effusion for lung cancer biomarker discovery by using multidimensional protein identification technology. J Proteome Res. 2011;10(10):4671-4682.

9. Schrohl AS, Würtz S, Kohn E, et al. Banking of biological fluids for studies of disease-associated protein biomarkers. Mol Cell Proteomics. 2008;7(10):2061-1066.

10. Yi EC, Marelli M, Lee H, et al. Approaching complete peroxisome characterization by gas-phase fractionation. Electrophoresis. 2002;23(18):3205-3216.

11. Kennedy J, Yi EC. Use of gas-phase fractionation to increase protein identifications: application to the peroxisome. Methods Mol Biol. 2008;432:217-228.

12. Brook RD, Rajagopalan S, Pope CA III, et al. Particulate matter air pollution and cardiovascular disease: An update to the scientific statement from the American Heart Association. Circulation. 2010;121(21):2331-2378.

13. Ho M, Wu KY, Chein HM, Chen LC, Cheng TJ. Pulmonary toxicity of inhaled nanoscale and fine zinc oxide particles: mass and surface area as an exposure metric. Inhal Toxicol. 2011;23(14):947-956.

14. Singh Y, Javier RN, Ehrman SH, Magnusson M, Deppert K. Approaches to increasing yield in evaporation/condensation nanoparticle generation. J Aerosol Sci. 2002;33(9):1309-1325.

15. Maciejczyk P, Zhong M, Li Q, Xiong J, Nadziejko C, Chen LC. Effects of subchronic exposures to concentrated ambient particles (CAPs) in mice. II. The design of a CAPs exposure system for biometric telemetry monitoring. Inhal Toxicol. 2005;17(4-5):189-197.

16. Moreno T, Gibbons W, Jones T, Richards R. The geology of ambient aerosols: characterising urban and rural/coastal silicate $\mathrm{PM}_{10-2.5}$ and $\mathrm{PM}_{2.5}$ using high-volume cascade collection and scanning electron microscopy. Atmos Environ. 2003;37(30):4265-4276. 
17. Jones T, Moreno T, BéruBé K, Richards R. The physicochemical characterisation of microscopic airborne particles in south Wales: a review of the locations and methodologies. Sci Total Environ. 2006;360(1-3):43-59.

18. Pichavant M, Goya S, Hamelmann E, Gelfand EW, Umetsu DT. Animal models of airway sensitization. Curr Protoc Immunol. 2007; Chapter 15:Unit 15.18.

19. Li N, Wang M, Bramble LA, et al. The adjuvant effect of ambient particulate matter is closely reflected by the particulate oxidant potential Environ Health Perspect. 2009;117(7):1116-1123.

20. Huang da W, Sherman BT, Tan Q, et al. DAVID Bioinformatics resources: expanded annotation database and novel algorithms to better extract biology from large gene lists. Nucleic Acids Res. 2007;35(Web Server issue):W169-W175.

21. Srivastava R, Ray S, Vaibhav V, et al. Serum profiling of leptospirosis patients to investigate proteomic alterations. J Proteomics. 2012;76 Spec No:56-68.

22. Sul D. Evaluation of toxicological monitoring markers using proteomic analysis. J Proteome Res. 2006;5(10):2525-2526.

23. Kennedy S. The role of proteomics in toxicology: identification of biomarkers of toxicity by protein expression analysis. Biomarkers. 2002;7(4):269-290.

24. Driscoll KE, Costa DL, Hatch G, et al. Intratracheal instillation as an exposure technique for the evaluation of respiratory tract toxicity: uses and limitations. Toxicol Sci. 2000;55(1):24-35.

25. Eggersdorfer ML, Kadau D, Herrmann HJ, Pratsinis SE. Aggregate morphology evolution by sintering: number and diameter of primary particles. J Aerosol Sci. 2012;46:7-19.

26. Gharib SA, Nguyen EV, Lai Y, Plampin JD, Goodlett DR, Hallstrand TS Induced sputum proteome in healthy subjects and asthmatic patients. J Allergy Clin Immunol. 2011;128(6):1176-1184. e6.

27. Tyan YC, Wu HY, Lai WW, Su WC, Liao PC. Proteomic profiling of human pleural effusion using two-dimensional nano liquid chromatography tandem mass spectrometry. J Proteome Res. 2005;4:1274-1286.
28. Izzotti A, Bagnasco M, Cartiglia C, et al. Chemoprevention of genome, transcriptome, and proteome alterations induced by cigarette smoke in rat lung. Eur J Cancer. 2005;41(13):1864-1874.

29. Kang X, Li N, Wang M, et al.Adjuvant effects of ambient particulate matter monitored by proteomics of bronchoalveolar lavage fluid. Proteomics. 2010;10: 520-531.

30. Chuang HC, Cheng YL, Lei YC, Chang HH, Cheng TJ. Protective effects of pulmonary epithelial lining fluid on oxidative stress and DNA single-strand breaks caused by ultrafine carbon black, ferrous sulphate and organic extract of diesel exhaust particles. Toxicol Appl Pharmacol. 2013;266(3):329-334.

31. Chuang HC, Fan CW, Chen KY, Chang-Chien GP, Chan CC. Vasoactive alteration and inflammation induced by polycyclic aromatic hydrocarbons and trace metals of vehicle exhaust particles. Toxicol Lett. 2012;214:131-136.

32. Jun EA, Lim KM, Kim K, et al. Silver nanoparticles enhance thrombus formation through increased platelet aggregation and procoagulant activity. Nanotoxicology. 2011;5(2):157-167.

33. Bezemer GF, Bauer SM, Oberdörster G, et al. Activation of pulmonary dendritic cells and Th2-type inflammatory responses on instillation of engineered, environmental diesel emission source or ambient air pollutant particles in vivo. J Innate Immun. 2011;3(2):150-166.

34. Kelly FJ. Oxidative stress: its role in air pollution and adverse health effects. Occup Environ Med. 2003;60(8):612-616.

35. Kiyohara C, Washio M, Horiuchi T, et al. Cigarette smoking, alcohol consumption, and risk of systemic lupus erythematosus: a case-control study in a Japanese population. J Rheumatol. 2012;39(7):1363-1370.

36. Bernatsky S, Fournier M, Pineau CA, Clarke AE, Vinet E, Smargiassi A Associations between ambient fine particulate levels and disease activity in patients with systemic lupus erythematosus (SLE). Environ Health Perspect. 2011;119(1):45-49.

37. Atta AM, Sousa CP, Carvalho EM, Sousa-Atta ML. Immunoglobulin E and systemic lupus erythematosus. Braz J Med Biol Res. 2004;37(10):1497-1501. 


\section{Supplementary tables}

The following tables present the protein profiles in BALF and

plasma that do not appear in the main part of the article.

Table SI Silver nanoparticle-unique proteins expressed in bronchoalveolar lavage fluid in the control mice

\begin{tabular}{|c|c|c|c|c|c|}
\hline No & Name of protein & $\begin{array}{l}\text { Mascot* } \\
\text { score }\end{array}$ & $\begin{array}{l}\text { Calculated Mw } \\
\text { (Dalton) }\end{array}$ & $\begin{array}{l}\text { Sequence } \\
\text { covered } \%\end{array}$ & Calculated pl \\
\hline I & Polymeric immunoglobulin receptor & 775 & 86,257 & 15.3 & 5.26 \\
\hline 2 & Serine protease inhibitor $\mathrm{A} 3 \mathrm{~N}$ & 650 & 46,859 & 18.4 & 5.59 \\
\hline 3 & Fibronectin & 243 & 276,017 & 3.7 & 5.39 \\
\hline 4 & Ig kappa chain $C$ region & 218 & 11,942 & 13.2 & 5.23 \\
\hline 5 & Histone H4 & 173 & 11,360 & 21.4 & 11.36 \\
\hline 6 & Fatty acid-binding protein, adipocyte & 159 & 14,755 & 9.8 & 8.53 \\
\hline 7 & Ig heavy chain $\mathrm{V}$ region MOPC 47A & 125 & $|3,08|$ & 23.1 & 8.99 \\
\hline 8 & Heat shock 70 kDa protein 4 & 122 & 94,872 & 3.3 & 5.15 \\
\hline 9 & Resistin-like alpha & 117 & 12,612 & 13.5 & 5.18 \\
\hline 10 & Myosin-9 & 107 & 227,429 & 1.7 & 5.54 \\
\hline II & Extracellular superoxide dismutase $(\mathrm{Cu}-\mathrm{Zn})$ & 105 & 27,717 & 10.8 & 6.36 \\
\hline 12 & Histone $\mathrm{H} 2 \mathrm{~A}$ type $\mathrm{I}-\mathrm{F}$ & 101 & 14,153 & 22.3 & 11.05 \\
\hline 13 & Properdin & 100 & 52,802 & 7.1 & 8.25 \\
\hline 14 & Complement component $\mathrm{C} 8$ alpha chain & 94 & 67,691 & 6.1 & 6.14 \\
\hline 15 & Ig heavy chain $\mathrm{V}$ region $44 \mathrm{I}$ & 93 & 13,074 & 33.6 & 8.46 \\
\hline 16 & Protein Z-dependent protease inhibitor & 84 & 51,878 & 2.7 & 5.49 \\
\hline 17 & Tubulin alpha-IA chain & 80 & 50,788 & 4.4 & 4.94 \\
\hline 18 & Proteasome subunit alpha type- 6 & 78 & 27,811 & 5.3 & 6.34 \\
\hline 19 & Ig lambda-I chain C region & 76 & 11,739 & 16.2 & 5.87 \\
\hline 20 & Proteasome subunit alpha type- 3 & 76 & 28,615 & 4.7 & 5.29 \\
\hline 21 & Proteasome subunit beta type- 8 & 73 & 30,526 & 9.1 & 6.22 \\
\hline 22 & Cathepsin B & 73 & 38,168 & 7.1 & 5.57 \\
\hline 23 & Fibrinogen gamma chain & 72 & 50,044 & 5.5 & 5.54 \\
\hline 24 & Complement factor $\mathrm{H}$ & 69 & 143,722 & 1.0 & 6.67 \\
\hline 25 & Transitional endoplasmic reticulum ATPase & 69 & 89,950 & 1.5 & 5.14 \\
\hline 26 & CDI77 antigen & 69 & 90,284 & 1.3 & 5.43 \\
\hline 27 & Peptidyl-prolyl cis-trans isomerase B & 68 & 23,699 & 6.0 & 9.56 \\
\hline 28 & SUMO-activating enzyme subunit I & 68 & 39,052 & 3.4 & 5.24 \\
\hline 29 & Annexin A2 & 66 & 38,937 & 6.5 & 7.55 \\
\hline 30 & Intercellular adhesion molecule I & 65 & 59,605 & 2.6 & 5.79 \\
\hline 31 & Ig alpha chain $C$ region & 65 & 37,594 & 4.4 & 4.97 \\
\hline 32 & Interleukin-I receptor accessory protein & 63 & 66,383 & 1.9 & 7.85 \\
\hline 33 & Myosin light polypeptide 6 & 63 & 17,090 & 16.6 & 4.56 \\
\hline 34 & Alpha-actinin-4 & 63 & 105,368 & 3.2 & 5.25 \\
\hline 35 & Isocitrate dehydrogenase (NADP), mitochondrial & 63 & 51,330 & 2.9 & 8.88 \\
\hline 36 & Keratin, type II cytoskeletal I & 62 & 66,079 & 1.7 & 8.39 \\
\hline 37 & Keratin, type II cytoskeletal 2 epidermal & 61 & 71,336 & 2.0 & 8.26 \\
\hline 38 & Microsomal glutathione S-transferase I & 59 & 17,597 & 8.4 & 9.67 \\
\hline 39 & Vimentin & 59 & 53,712 & 2.4 & 5.06 \\
\hline 40 & Alpha/beta hydrolase domain-containing protein I4B & 58 & 22,551 & 6.7 & 5.82 \\
\hline 41 & Dipeptidyl peptidase I & 58 & $53,|4|$ & 2.6 & 6.41 \\
\hline 42 & Heterogeneous nuclear ribonucleoproteins A2/BI & 58 & 37,437 & 2.8 & 8.97 \\
\hline 43 & Brain acid soluble protein I & 56 & 22,074 & 6.2 & 4.50 \\
\hline 44 & $60 \mathrm{~S}$ acidic ribosomal protein $\mathrm{PO}$ & 56 & 34,366 & 3.5 & 5.91 \\
\hline 45 & Transforming growth factor-beta-induced protein ig-h3 & 56 & 75,177 & 2.0 & 6.62 \\
\hline 46 & Glutathione reductase, mitochondrial & 55 & 54,256 & 2.6 & 8.19 \\
\hline 47 & Ig heavy chain $\vee$ region MOPC I04E & 54 & 13,089 & 16.2 & 6.84 \\
\hline 48 & Proteasome assembly chaperone I & 53 & 33,938 & 4.8 & 6.05 \\
\hline 49 & Apolipoprotein E & 52 & 35,901 & 8.7 & 5.56 \\
\hline 50 & Alpha-2-antiplasmin & 52 & 55,165 & 2.9 & 5.85 \\
\hline
\end{tabular}


Table SI (Continued)

\begin{tabular}{|c|c|c|c|c|c|}
\hline No & Name of protein & $\begin{array}{l}\text { Mascot* } \\
\text { score }\end{array}$ & $\begin{array}{l}\text { Calculated Mw } \\
\text { (Dalton) }\end{array}$ & $\begin{array}{l}\text { Sequence } \\
\text { covered } \%\end{array}$ & Calculated pl \\
\hline 51 & Ig heavy chain V-III region $\mathrm{J} 606$ & 52 & 12,916 & 11.3 & 6.86 \\
\hline 52 & Phosphoglucomutase-I & 52 & 61,665 & 2.1 & 6.14 \\
\hline 53 & Proteasome subunit alpha type-I & 51 & 29,813 & 4.9 & 6.00 \\
\hline 54 & Growth arrest-specific protein 6 & 50 & 76,500 & 1.8 & 5.34 \\
\hline 55 & Poly(rC)-binding protein I & 49 & 37,987 & 3.1 & 6.66 \\
\hline 56 & Hepatocyte growth factor activator & 49 & 72,860 & 2.6 & 6.65 \\
\hline 57 & Epididymal secretory protein EI & 48 & 16,774 & 8.1 & 7.59 \\
\hline 58 & $\mathrm{Na}(+) / \mathrm{H}(+)$ exchange regulatory cofactor NHE-RF I & 48 & 38,862 & 3.9 & 5.63 \\
\hline 59 & Complement C2 & 45 & 85,942 & 1.6 & 7.52 \\
\hline 60 & Plasma protease $\mathrm{Cl}$ inhibitor & 45 & 55,834 & 2.2 & 5.87 \\
\hline 61 & Peptidoglycan recognition protein I & 45 & 20,875 & 6.6 & 7.07 \\
\hline 62 & $\begin{array}{l}\text { Small glutamine-rich tetratricopeptide repeat- } \\
\text { containing protein alpha }\end{array}$ & 45 & 34,529 & 4.1 & 4.99 \\
\hline 63 & Leukemia inhibitory factor receptor & 44 & 123,808 & 1.2 & 5.70 \\
\hline 64 & Lamin-BI & 43 & 66,973 & 2.4 & 5.11 \\
\hline 65 & Nuclease-sensitive element-binding protein I & 42 & 35,709 & 4.7 & 9.87 \\
\hline 66 & LIM and SH3 domain protein I & 42 & 30,374 & 4.9 & 6.61 \\
\hline 67 & Cathepsin Z & 42 & 34,658 & 3.6 & 6.13 \\
\hline 68 & C-C motif chemokine 6 & 42 & 13,318 & 9.5 & 9.50 \\
\hline 69 & Myosin regulatory light polypeptide 9 & 40 & 19,898 & 5.8 & 4.80 \\
\hline 70 & 605 ribosomal protein $\mathrm{L7}$ & 40 & 31,457 & 4.8 & 10.89 \\
\hline 71 & Tetranectin & 39 & 22,642 & 6.9 & 5.50 \\
\hline 72 & Chloride intracellular channel protein 5 & 38 & 28,440 & 4.8 & 5.64 \\
\hline 73 & Aminopeptidase $\mathrm{N}$ & 38 & 110,038 & 1.3 & 5.62 \\
\hline 74 & Thyroglobulin & 38 & 311,291 & 0.4 & 5.32 \\
\hline 75 & Ribonuclease 4 & 37 & 17,470 & 8.1 & 9.18 \\
\hline 76 & Pulmonary surfactant-associated protein $C$ & 37 & 21,269 & 9.3 & 6.42 \\
\hline 77 & Cystatin-C & 37 & 15,749 & $\mathrm{I} \mid .4$ & 9.18 \\
\hline 78 & Epidermal growth factor receptor & 37 & 138,187 & 1.5 & 6.46 \\
\hline 79 & Glyoxylate reductase/hydroxypyruvate reductase & 37 & 35,706 & 3.7 & 7.57 \\
\hline 80 & $\begin{array}{l}\text { LIM and calponin homology domains-containing } \\
\text { protein I }\end{array}$ & 37 & 119,035 & 1.2 & 5.38 \\
\hline 81 & Myeloperoxidase & 37 & 82,042 & $\mathrm{I} .5$ & 9.63 \\
\hline 82 & Cell division cycle protein 27 homolog & 36 & 92,868 & 1.5 & 6.59 \\
\hline 83 & Carbonic anhydrase 6 & 36 & 36,586 & 3.8 & 6.11 \\
\hline 84 & Lumican & 36 & 38,640 & 3.3 & 6.00 \\
\hline 85 & Zinc-alpha-2-glycoprotein & 35 & 35,538 & 5.9 & 5.83 \\
\hline 86 & Calreticulin & 35 & 48,136 & 3.1 & 4.33 \\
\hline 87 & Kinesin-I heavy chain & 34 & 110,225 & 1.7 & 6.06 \\
\hline 88 & Inter-alpha-trypsin inhibitor heavy chain $\mathrm{H} 2$ & 33 & $|06,26|$ & 1.3 & 6.82 \\
\hline 89 & Glucosidase 2 subunit beta & 33 & 59,725 & 2.3 & 4.41 \\
\hline 90 & Ubiquitin carboxyl-terminal hydrolase 5 & 33 & 96,685 & 1.5 & 4.89 \\
\hline 91 & Sulfhydryl oxidase I & 33 & 83,531 & 1.7 & 6.73 \\
\hline 92 & Lysozyme C-I & 33 & 17,240 & 8.1 & 9.55 \\
\hline 93 & Ubiquitin carboxyl-terminal hydrolase 14 & 33 & 56,422 & 2.8 & 5.15 \\
\hline 94 & EF-hand domain-containing protein D2 & 32 & 26,775 & 5.0 & 5.01 \\
\hline 95 & Lymphocyte-specific protein I & 32 & 36,806 & 3.9 & 4.77 \\
\hline 96 & Hepatoma-derived growth factor & 32 & 26,367 & 8.4 & 4.80 \\
\hline 97 & Aspartyl aminopeptidase & 32 & 52,744 & 3.0 & 6.82 \\
\hline 98 & Glyoxalase domain-containing protein 4 & 32 & 33,581 & 5.0 & 5.28 \\
\hline 99 & Fatty acid synthase & 32 & 274,994 & 0.4 & 6.13 \\
\hline 100 & Dihydropyrimidinase-related protein I & 32 & 62,471 & 2.8 & 6.63 \\
\hline 101 & Nuclear migration protein nudC & 31 & 38,334 & 3.3 & 5.17 \\
\hline 102 & Taxl-binding protein 3 & 31 & $13,7 \mid 4$ & 13.7 & 8.04 \\
\hline 103 & Inter-alpha-trypsin inhibitor, heavy chain 4 & 31 & 104,765 & 1.5 & 5.99 \\
\hline 104 & Complement factor I & 31 & 69,497 & 2.5 & 7.57 \\
\hline 105 & Von Willebrand factor A domain-containing protein $5 \mathrm{~A}$ & 31 & 87,829 & $\mathrm{I} .5$ & 6.15 \\
\hline 106 & Vomeromodulin & 30 & 62,751 & 2.0 & 5.46 \\
\hline
\end{tabular}

Note: *Matrix Science, Boston, MA, USA.

Abbreviations: CD, cluster of differentiation; Ig, immunoglobulin; NADPH, nicotinamide adenine dinucleotide phosphate; SUMO, small ubiquitin-like modifier. 
Table S2 Silver nanoparticle-unique proteins expressed in bronchoalveolar lavage fluid in the allergy mice

\begin{tabular}{|c|c|c|c|c|c|}
\hline No & Name of protein & $\begin{array}{l}\text { Mascot* } \\
\text { score }\end{array}$ & $\begin{array}{l}\text { Calculated Mw } \\
\text { (Dalton) }\end{array}$ & $\begin{array}{l}\text { Sequence } \\
\text { covered \% }\end{array}$ & Calculated pl \\
\hline 1 & Actin, aortic smooth muscle & 523 & 42,381 & 22.3 & 5.23 \\
\hline 2 & Glutathione peroxidase 3 & 179 & 25,580 & 15.0 & 8.33 \\
\hline 3 & Protein SI00-A9 & 174 & $13,21 \mid$ & 23.0 & 6.64 \\
\hline 4 & BPI fold-containing family A member I & 169 & 28,778 & 6.8 & 6.02 \\
\hline 5 & Fibrinogen beta chain & 150 & 55,402 & 9.8 & 6.68 \\
\hline 6 & Nucleoside diphosphate kinase B & 143 & 17,466 & 28.3 & 6.97 \\
\hline 7 & Apolipoprotein E & 134 & 35,901 & 12.9 & 5.56 \\
\hline 8 & Serpin B6 & 133 & 42,913 & 6.6 & 5.53 \\
\hline 9 & Ig heavy chain $\mathrm{V}$-III region $\mathrm{A} 4$ & 116 & $|2,78|$ & 22.1 & 7.00 \\
\hline 10 & ADP-ribosylation factor I & 109 & $20,74 I$ & 14.4 & 6.32 \\
\hline II & Myosin light polypeptide 6 & 91 & 17,090 & 16.6 & 4.56 \\
\hline 12 & Ig gamma-3 chain $C$ region & 90 & 44,472 & 2.0 & 6.68 \\
\hline 13 & Heterogeneous nuclear ribonucleoproteins A2/BI & 89 & 37,437 & 6.2 & 8.97 \\
\hline 14 & Ig kappa chain V-V region K2 (Fragment) & 89 & 12,744 & 8.7 & 8.50 \\
\hline 15 & Advanced glycosylation end product-specific receptor & 80 & 42,984 & 5.2 & 5.78 \\
\hline 16 & Transitional endoplasmic reticulum ATPase & 78 & 89,950 & 4.6 & 5.14 \\
\hline 17 & Creatine kinase M-type & 74 & 43,246 & 7.9 & 6.58 \\
\hline 18 & CD5 antigen-like & 71 & 40,320 & 6.3 & 5.01 \\
\hline 19 & Ig heavy chain $\vee$ region $93 \mathrm{G} 7$ & 70 & 15,619 & 7.1 & 8.50 \\
\hline 20 & Ig alpha chain $\mathrm{C}$ region & 69 & 37,594 & 4.4 & 4.97 \\
\hline 21 & Carbonic anhydrase 3 & 68 & 29,633 & 8.1 & 6.89 \\
\hline 22 & Myotrophin & 64 & 13,024 & 14.4 & 5.27 \\
\hline 23 & Ig kappa chain V-V region L7 (Fragment) & 61 & $|2,72|$ & 10.4 & 5.63 \\
\hline 24 & Tropomyosin beta chain & 61 & 32,931 & 7.7 & 4.66 \\
\hline 25 & Ig heavy chain $\mathrm{V}$ region MOPC 47A & 60 & $|3,08|$ & 13.7 & 8.99 \\
\hline 26 & Glycogenin-I & 60 & 37,606 & 4.2 & 5.06 \\
\hline 27 & Ig kappa chain V19-17 & 59 & 16,537 & 6.0 & 6.38 \\
\hline 28 & Aminopeptidase B & 57 & 73,054 & 1.5 & 5.22 \\
\hline 29 & Cytosolic nonspecific dipeptidase & 57 & 53,190 & 2.3 & 5.43 \\
\hline 30 & Proteasome subunit beta type- 4 & 56 & 29,211 & 3.8 & 5.47 \\
\hline 31 & Ig heavy chain $V$ region 44 I & 56 & 13,074 & 13.8 & 8.46 \\
\hline 32 & Histone $\mathrm{H} 4$ & 56 & 11,360 & 9.7 & 11.36 \\
\hline 33 & 6-phosphogluconate dehydrogenase, decarboxylating & 56 & 53,726 & 2.3 & 6.81 \\
\hline 34 & Keratin, type I cytoskeletal 10 & 55 & 57,906 & 2.8 & 5.04 \\
\hline 35 & Transforming protein RhoA & 53 & 22,110 & 9.8 & 5.83 \\
\hline 36 & BPI fold-containing family B member I & 53 & 52,593 & 4.9 & 5.96 \\
\hline 37 & Carbonyl reductase (NADPH) I & 52 & 30,907 & 3.2 & 8.53 \\
\hline 38 & Glyoxalase domain-containing protein 4 & 51 & 33,581 & 6.0 & 5.28 \\
\hline 39 & Extracellular superoxide dismutase (Cu-Zn) & 50 & 27,717 & 5.6 & 6.36 \\
\hline 40 & Ig lambda-I chain $\mathrm{C}$ region & 49 & 11,739 & 32.4 & 5.87 \\
\hline 41 & Basal cell adhesion molecule & 49 & 68,426 & 2.3 & 5.85 \\
\hline 42 & Alcohol dehydrogenase $[\mathrm{NADP}(+)]$ & 49 & 36,792 & 4.9 & 6.90 \\
\hline 43 & Myoglobin & 49 & 17,116 & 11.0 & 7.07 \\
\hline 44 & Ig kappa chain V-II region I7S29.I & 48 & 12,496 & 11.5 & 7.97 \\
\hline 45 & Protein SI00-AII & 48 & 11,247 & 7.1 & 5.28 \\
\hline 46 & Annexin $A 2$ & 48 & 38,937 & 3.2 & 7.55 \\
\hline 47 & Inter-alpha-trypsin inhibitor heavy chain $\mathrm{H} 2$ & 48 & 106,261 & 1.6 & 6.82 \\
\hline 48 & Heterogeneous nuclear ribonucleoprotein $\mathrm{A} 3$ & 48 & 39,856 & 2.6 & 9.10 \\
\hline 49 & Myosin regulatory light polypeptide 9 & 47 & 19,898 & 5.2 & 4.80 \\
\hline 50 & Flavin reductase (NADPH) & 47 & 22,297 & 8.3 & 6.49 \\
\hline 51 & Band 3 anion transport protein & 46 & 103,412 & 1.0 & 5.31 \\
\hline 52 & Histone $\mathrm{H} 3.3 \mathrm{C}$ & 45 & 15,363 & 5.1 & 11.14 \\
\hline 53 & Histone $\mathrm{H} 2 \mathrm{~A}$ type $\mathrm{I}-\mathrm{F}$ & 45 & 14,153 & 6.9 & 11.05 \\
\hline 54 & Complement C4-B & 44 & 194,447 & 0.5 & 7.38 \\
\hline 55 & Heat shock 70 kDa protein 4 & 42 & 94,872 & 1.7 & 5.15 \\
\hline 56 & Ig lambda-2 chain $C$ region & 41 & 11,419 & 17.3 & 5.86 \\
\hline
\end{tabular}


Table S2 (Continued)

\begin{tabular}{|c|c|c|c|c|c|}
\hline No & Name of protein & $\begin{array}{l}\text { Mascot* } \\
\text { score }\end{array}$ & $\begin{array}{l}\text { Calculated Mw } \\
\text { (Dalton) }\end{array}$ & $\begin{array}{l}\text { Sequence } \\
\text { covered \% }\end{array}$ & Calculated pl \\
\hline 57 & Retinol-binding protein 4 & 40 & 23,533 & 5.0 & 5.69 \\
\hline 58 & Apolipoprotein A-II & 39 & 11,359 & 9.8 & 6.56 \\
\hline 59 & Talin-I & 38 & 271,820 & 0.4 & 5.84 \\
\hline 60 & Galectin-3 & 38 & 27,612 & 4.2 & 8.46 \\
\hline 61 & Chloride intracellular channel protein I & 38 & 27,338 & 5.0 & 5.09 \\
\hline 62 & Alpha-actinin-I & 37 & $|03,63|$ & I.I & 5.23 \\
\hline 63 & Vimentin & 36 & 53,712 & 2.4 & 5.06 \\
\hline 64 & Proteasome subunit alpha type-I & 36 & 29,813 & 4.9 & 6.00 \\
\hline 65 & L-xylulose reductase & 35 & 25,958 & 4.5 & 6.82 \\
\hline 66 & Coronin-IB & 35 & 54,505 & 1.4 & 5.54 \\
\hline 67 & Proteasome subunit beta type-7 & 35 & 30,214 & 3.6 & 8.14 \\
\hline 68 & Protein AMBP & 35 & 39,916 & 2.9 & 5.96 \\
\hline 69 & Filamin-A & 34 & 283,897 & 0.4 & 5.68 \\
\hline 70 & Alcohol dehydrogenase I & 34 & 40,601 & 1.9 & 8.44 \\
\hline 71 & Calmodulin & 33 & 16,827 & 4.7 & 4.09 \\
\hline 72 & Immunoglobulin J chain & 33 & 18,458 & 5.0 & 4.77 \\
\hline 73 & Proteasome subunit alpha type-7-like & 32 & 28,020 & 4.4 & 8.81 \\
\hline 74 & NADPH-cytochrome $\mathrm{P} 450$ reductase & 31 & 77,394 & 1.3 & 5.34 \\
\hline 75 & Cofilin-I & 31 & 18,776 & 4.8 & 8.22 \\
\hline 76 & Thiosulfate sulfurtransferase & 31 & 33,673 & 2.4 & 7.71 \\
\hline 77 & Leucine-rich repeat-containing protein I6A & 31 & 153,305 & 0.5 & 7.98 \\
\hline 78 & Cofilin-2 & 31 & 18,812 & 4.8 & 7.66 \\
\hline 79 & Phosphoglycerate kinase I & 30 & 44,921 & 2.6 & 8.02 \\
\hline
\end{tabular}

Note: *Matrix Science, Boston, MA, USA.

Abbreviations: AMBP, alpha-I-microglobulin/bikunin precursor; CD, cluster of differentiation; Ig, immunoglobulin; SUMO, small ubiquitin-like modifier.

Table S3 Silver nanoparticle-unique proteins expressed in plasma in the control mice

\begin{tabular}{|c|c|c|c|c|c|}
\hline No & Name of protein & $\begin{array}{l}\text { Mascot* } \\
\text { score }\end{array}$ & $\begin{array}{l}\text { Calculated Mw } \\
\text { (Dalton) }\end{array}$ & $\begin{array}{l}\text { Sequence } \\
\text { covered } \%\end{array}$ & Calculated pl \\
\hline I & Alpha-I-antitrypsin I-I & I,890 & 46,145 & 33.4 & 5.44 \\
\hline 2 & Apolipoprotein B-100 & 185 & 510,481 & 1.3 & 6.35 \\
\hline 3 & Complement C5 & 148 & 190,469 & 3.0 & 6.39 \\
\hline 4 & $\begin{array}{l}\text { Ig heavy chain } \vee \text { regions TEPC I5/SI07/HPCMI/ } \\
\text { HPCM } 2 / \mathrm{HPCM} 3\end{array}$ & 147 & 13,883 & 23.6 & 6.51 \\
\hline 5 & Immunoglobulin J chain & 140 & 18,458 & 16.4 & 4.77 \\
\hline 6 & Fetuin-B & 140 & 43,541 & 14.7 & 6.17 \\
\hline 7 & Ig kappa chain V-III region ABPC 22/PC 9245 & 125 & 12,148 & 30.6 & 4.90 \\
\hline 8 & Fructose-bisphosphate aldolase B & 116 & 39,938 & 7.1 & 8.52 \\
\hline 9 & Keratin, type II cytoskeletal Ib & 115 & 61,379 & 4.2 & 7.74 \\
\hline 10 & Ig kappa chain V-VI region NQ2-I7.4.I & 104 & 11,668 & 24.3 & 9.43 \\
\hline 11 & Serum amyloid A-I protein & 102 & 13,876 & 18.9 & 6.50 \\
\hline 12 & Carboxypeptidase $\mathrm{N}$ subunit 2 & 100 & 61,296 & 5.1 & 5.53 \\
\hline 13 & Lumican & 88 & 38,640 & 6.2 & 6.00 \\
\hline 14 & Ig heavy chain $V$ region MOPC 2 I (Fragment) & 83 & 15,232 & 16.2 & 8.83 \\
\hline 15 & Ig heavy chain $\vee$ region 44 I & 83 & 13,074 & 10.3 & 8.46 \\
\hline 16 & Ig heavy chain $\mathrm{V}$ region $5-84$ & 79 & 13,035 & 23.1 & 9.05 \\
\hline 17 & Carboxypeptidase B2 & 71 & 49,239 & 5.5 & 8.03 \\
\hline 18 & Complement component $\mathrm{C} 8$ beta chain & 68 & 68,011 & 2.2 & 8.07 \\
\hline 19 & Ig heavy chain V-III region $\mathrm{A} 4$ & 68 & $|2,78|$ & 8.0 & 7.00 \\
\hline 20 & Complement $\mathrm{Clq}$ subcomponent subunit $\mathrm{B}$ & 63 & 26,929 & 4.7 & 8.30 \\
\hline 21 & Flavin reductase (NADPH) & 62 & 22,297 & 4.9 & 6.49 \\
\hline 22 & Coagulation factor XIII B chain & 61 & 78,426 & 1.6 & 6.56 \\
\hline 23 & Interleukin-I receptor accessory protein & 56 & 66,383 & 4.2 & 7.85 \\
\hline 24 & Thrombospondin-I & 56 & 133,555 & 1.0 & 4.72 \\
\hline 25 & Complement component $\mathrm{C} 8$ gamma chain & 52 & 22,665 & 6.9 & 9.37 \\
\hline
\end{tabular}


Table S3 (Continued)

\begin{tabular}{|c|c|c|c|c|c|}
\hline No & Name of protein & $\begin{array}{l}\text { Mascot* } \\
\text { score }\end{array}$ & $\begin{array}{l}\text { Calculated Mw } \\
\text { (Dalton) }\end{array}$ & $\begin{array}{l}\text { Sequence } \\
\text { covered \% }\end{array}$ & Calculated pl \\
\hline 26 & Complement component C8 alpha chain & 48 & 67,691 & 2.2 & 6.14 \\
\hline 27 & Ig kappa chain V-V region K2 (Fragment) & 47 & 12,744 & 8.7 & 8.50 \\
\hline 28 & Vitamin K-dependent protein Z & 46 & 45,587 & 3.3 & 5.60 \\
\hline 29 & Keratin, type II cytoskeletal 2 oral & 43 & 63,319 & 1.5 & 8.68 \\
\hline 30 & Carboxypeptidase $\mathrm{N}$ catalytic chain & 42 & 52,098 & 2.6 & 8.42 \\
\hline 31 & Nesprin-I & 40 & $1,016,650$ & 0.1 & 5.43 \\
\hline 32 & Zinc-alpha-2-glycoprotein & 40 & 35,538 & 3.9 & 5.83 \\
\hline 33 & Fibroblast growth factor I & 39 & 17,578 & 20.0 & 6.52 \\
\hline 34 & Proteasome subunit beta type- 6 & 38 & 25,591 & 4.6 & 4.97 \\
\hline 35 & Laminin subunit alpha-5 & 36 & 416,165 & 0.5 & 6.28 \\
\hline 36 & Immunoglobulin superfamily member 10 & 35 & 287,757 & 0.3 & 9.38 \\
\hline 37 & Ig kappa chain V-II region 7S34.I & 34 & 12,659 & II.5 & 8.89 \\
\hline 38 & Ig heavy chain $V$ region $93 \mathrm{G} 7$ & 34 & 15,619 & 7.1 & 8.50 \\
\hline 39 & Vasohibin-I & 32 & 42,020 & 2.9 & 9.42 \\
\hline 40 & Ig gamma- $2 A$ chain $C$ region, $A$ allele & 31 & 36,936 & 5.8 & 7.23 \\
\hline
\end{tabular}

Note: *Matrix Science, Boston, MA, USA

Abbreviations: Ig, immunoglobulin; NADP: nicotinamide adenine dinucleotide phosphate.

Table S4 Silver nanoparticle-unique proteins expressed in plasma in the allergy mice

\begin{tabular}{|c|c|c|c|c|c|}
\hline No & Name of protein & $\begin{array}{l}\text { Mascot* } \\
\text { score }\end{array}$ & $\begin{array}{l}\text { Calculated Mw } \\
\text { (Dalton) }\end{array}$ & $\begin{array}{l}\text { Sequence } \\
\text { covered } \%\end{array}$ & Calculated pl \\
\hline I & Ig alpha chain $\mathrm{C}$ region & 157 & 37,594 & 7.3 & 4.97 \\
\hline 2 & Ig kappa chain V-VI region NQ2-6.I & 113 & 11,820 & 14.8 & 8.98 \\
\hline 3 & Vitronectin & 108 & 55,613 & 5.2 & 5.67 \\
\hline 4 & Inhibitor of carbonic anhydrase & 91 & 78,711 & 3.1 & 7.00 \\
\hline 5 & Prothrombin & 81 & 71,649 & 2.1 & 6.04 \\
\hline 6 & Leukemia inhibitory factor receptor & 71 & 123,808 & 1.2 & 5.70 \\
\hline 7 & Coagulation factor $X$ & 69 & 55,409 & 4.8 & 5.50 \\
\hline 8 & Inter-alpha-trypsin inhibitor heavy chain $\mathrm{HI}$ & 65 & 101,460 & 1.4 & 6.49 \\
\hline 9 & Carboxypeptidase $\mathrm{N}$ subunit 2 & 61 & 61,296 & 2.9 & 5.53 \\
\hline 10 & Ig kappa chain V-II region I7S29.I & 61 & 12,496 & 11.5 & 7.97 \\
\hline II & Apolipoprotein C-IV & 57 & 14,450 & 16.1 & 9.64 \\
\hline 12 & Plasma kallikrein & 56 & 73,446 & 1.6 & 8.40 \\
\hline 13 & Superoxide dismutase (Cu-Zn) & 56 & 16,104 & 7.8 & 6.02 \\
\hline 14 & Ig kappa chain V19-I7 & 50 & 16,537 & 6.0 & 6.38 \\
\hline 15 & Mannose-binding protein A & 48 & 25,836 & 3.8 & 7.55 \\
\hline 16 & Zinc-alpha-2-glycoprotein & 45 & 35,538 & 5.9 & 5.83 \\
\hline 17 & Apolipoprotein C-II & 38 & 10,734 & 9.3 & 4.78 \\
\hline 18 & Ig heavy chain $\mathrm{V}$ region $\mathrm{BI}-8 / \mathrm{I} 86-2$ & 35 & $|5,58|$ & 5.0 & 8.94 \\
\hline 19 & Apolipoprotein D & 35 & 21,744 & 3.7 & 4.82 \\
\hline 20 & Prolow-density lipoprotein receptor-related protein I & 35 & 523,342 & 0.2 & 5.14 \\
\hline 21 & Dystrophin & 33 & 427,676 & 0.3 & 5.66 \\
\hline 22 & Sulfhydryl oxidase I & 32 & 83,531 & 0.9 & 6.73 \\
\hline 23 & Betaine-homocysteine S-methyltransferase I & 32 & 45,448 & 2.5 & 8.01 \\
\hline 24 & Vasohibin-I & 32 & 42,020 & 2.9 & 9.42 \\
\hline 25 & Interleukin-I receptor accessory protein & 31 & 66,383 & 1.8 & 7.85 \\
\hline 26 & E3 ubiquitin-protein ligase RNFI23 & 30 & 150,040 & 0.5 & 6.25 \\
\hline
\end{tabular}

Note: *Matrix Science, Boston, MA, USA.

Abbreviation: Ig, immunoglobulin. 
International Journal of Nanomedicine

Dovepress

\section{Publish your work in this journal}

The International Journal of Nanomedicine is an international, peerreviewed journal focusing on the application of nanotechnology in diagnostics, therapeutics, and drug delivery systems throughou the biomedical field. This journal is indexed on PubMed Central, MedLine, CAS, SciSearch ${ }^{\circledR}$, Current Contents ${ }^{\circledR} /$ Clinical Medicine,
Journal Citation Reports/Science Edition, EMBase, Scopus and the Elsevier Bibliographic databases. The manuscript management system is completely online and includes a very quick and fair peer-review system, which is all easy to use. Visit http://www.dovepress.com/ testimonials.php to read real quotes from published authors.

Submit your manuscript here: http://www.dovepress.com/international-journal-of-nanomedicine-journal 